\title{
Elimination of Salmonella enterica serotype Enteritidis in intestinal epithelial cells by mechanisms other than nitric oxide
}

\author{
MARJA SAARINEN*, PÄIVI EKMAN*, QIUSHUI HE*,+ MAKOTO IKEDA $\ddagger$, MIKA VIRTALA*, \\ DAVID T. Y. YUt, HEIKKI ARVILOMMI* and KAISA GRANFORS* \\ *National Public Health Institute, Department in Turku, Turku, Finland, †Department of Paediatrics, Turku \\ University Hospital, Turku, Finland, and †UCLA School of Medicine, Los Angeles, CA 90095, USA
}

\begin{abstract}
Production of nitric oxide (NO) by intestinal epithelial cells is induced after infection with Salmonella spp. or some other enteroinvasive bacteria. However, direct evidence of the role of NO in the elimination of intracellular pathogens in intestinal mucosa has not been established. This study investigated whether NO mediates killing of Salmonella enterica serovar Enteritidis in human intestinal epithelial cells by using parent Henle407 cell line and a transfected cell line not capable of induced NO production (HenleNO $\left.{ }^{\text {def }}\right)$. NO synthesis was studied as combined accumulation of nitrite and nitrate, as inducible nitric oxide synthase (iNOS) protein determined by Western blotting and as iNOS mRNA detected by reverse transcription (RT)-PCR. Although parent and HenleNO ${ }^{\text {def }}$ cells differed markedly in their ability to produce NO after infection, they eliminated $S$. Enteritidis equally, as determined by cfu counts. The presence of aminoguanidine, a selective iNOS inhibitor, during the infection blocked the production of NO but did not affect the elimination of the bacteria. These data suggest that NO does not have a direct role in the elimination of intracellular Salmonellae by human intestinal epithelial cells.
\end{abstract}

\section{Introduction}

Nitric oxide (NO) is a low mol. wt gas produced from L-arginine by the nitric oxide synthase (NOS) enzyme. $\mathrm{NO}$ is produced in numerous physiological and pathological conditions, including inflammation and host defence against microbes and parasites [1]. It can be produced either constitutively or after stimulation of inducible nitric oxide synthase (iNOS) by, for example, pro-inflammatory cytokines and bacterial lipopolysaccharide (LPS) [2]. There is evidence that NO plays a part in mucosal inflammation and defence against infections. NO has been shown to be induced in bowel inflammation in human disease [3,4] and in experimental animal models [5,6]. Data have also been presented indicating the role of NO in the inhibition of intracellular multiplication of Chlamydia trachomatis in epithelial cells [7] and two recent studies have

Received 26 Jan. 2001; revised version received 16 May 2001; accepted 16 May 2001.

Corresponding author: Dr K. Granfors (e-mail: kaisa. granfors@utu.fi). demonstrated induction of NO synthesis by Salmonella enterica serovar Dublin in cultured human enterocytes $[8,9]$. These results suggest a role for NO in the elimination of microbes in mucosal infections.

Previous studies with a $S$. Enteritidis-infected human intestinal epithelial cell line (Henle-407) demonstrated that, during a follow-up period of 2 weeks, the number of viable intracellular bacteria diminished but several bacteria were still able to survive inside the cells [10]. In the same study, a marked amount of nitrite, the stable end product of NO metabolism, was detected in the cell culture supernate of Henle-407 cells after infection with $S$. Enteritidis. This indicated that the Henle-407 cell line is appropriate for studying the role of NO in elimination of salmonellae. Therefore, the present study evaluated whether killing of intracellular $S$. Enteritidis in Henle cells was associated with production of NO. To be able to verify the role of $\mathrm{NO}$ in the elimination process, a derivative of Henle cells that would not produce NO after infection with $S$. Enteritidis was needed. This type of clone is normally derived by a lengthy, haphazard and laborious cycle of 
culture and selection. Fortuitously, a Henle clone generated during transfection of the parent cells with the RSV5.neo selection vector failed to express $\mathrm{NO}$ on culture with salmonellae. Therefore, this cell line was used for the present study.

\section{Materials and methods}

\section{Cell cultures}

Human intestinal epithelial cells Henle-407 (CCL-6; American Type Culture Collection, Rockville, MD, USA) were cultured in Iscove's Modified Dulbecco's Medium (IMDM; Life Technologies, Paisley, Scotland) supplemented with heat-inactivated fetal calf serum (FCS; PAA Labor-und Forschungsgesellschaft $\mathrm{GmbH}$, Linz, Austria) 10\%, L-glutamine $1.8 \mathrm{mmol} / \mathrm{L}$ and gentamicin $50 \mathrm{mg} / \mathrm{L}$ (both from Biological Industries, Kibbutz Beit Haemek, Israel) at $37^{\circ} \mathrm{C}$ in a humidified atmosphere of air with $\mathrm{CO}_{2} 5 \%$. Cells were grown in disposable flasks or in 24-well plates (Greiner, Frickenhausen, Germany). The cationic lipid DOTAP method (Boehringer Mannheim Biochemica) was used for transfection with the RSV5.neo vector. A stable transfectant was selected and maintained with geneticin (Sigma) $0.5 \mathrm{~g} / \mathrm{L}$. Transfected cells were observed to be deficient in NO production after infection with salmonellae, and were thus designated as Henle$\mathrm{NO}^{\text {def }}$ cells.

The mouse monocyte/macrophage cell line J774.A1 (ATCC) was used as a control for NO synthesis. Cells were stimulated with mouse recombinant interferon (IFN)- $\gamma$ (200 IU/ml; Sigma) and $S$. Enteritidis lipopolysaccharide (LPS, $100 \mathrm{ng} / \mathrm{ml}$; Sigma) for $24 \mathrm{~h}$ (positive control) or used without such stimulation (negative control). All cell lines were routinely tested and shown to be free of mycoplasma contamination.

\section{Infection assay}

The strain of $S$. Enteritidis used was a stool isolate from a patient with salmonella-triggered reactive arthritis. The bacteria were grown in Luria-Bertani broth at $37^{\circ} \mathrm{C}$ to the logarithmic phase of growth. Cell lines were infected as described previously [10]. Briefly, confluent monolayers of Henle-407 cells were washed with Hanks's Balanced Salts Solution (HBSS), overlaid with fresh IMDM and co-cultured with $S$. Enteritidis (multiplicity of infection 40-60 bacteria/cell) for $2 \mathrm{~h}$ at $37^{\circ} \mathrm{C}$. The cells were washed four times with HBSS and overlaid with fresh IMDM supplemented with gentamicin $50 \mathrm{mg} / \mathrm{L}$. In some experiments, $1.0 \mathrm{mM}$ aminoguanidine, a selective iNOS inhibitor (AG; Sigma), was added to the cell culture medium $15 \mathrm{~min}$ before the infection, and again to the incubation medium after washes. After indicated periods, the cells were washed with HBSS, harvested and lysed, or lysed in the well, and the number of viable intracellular bacteria was determined as cfu as described previously [10]. Briefly, the cells were lysed with Triton X-100 1\%, 10-fold dilutions were made in microtitration plates, and $20 \mu \mathrm{l}$ of those dilutions were cultured on LB plates overnight at $37^{\circ} \mathrm{C}$, after which bacterial colonies on the plates were counted.

\section{Nitrite and nitrate $\left(N O_{x}\right)$ measurement}

Production of NO by salmonella-infected and noninfected Henle-407 cells was determined by measuring spectrophotometrically the combined accumulation of nitrite and nitrate $\left(\mathrm{NO}_{\mathrm{x}}\right)$ in the cell culture supernate. A commercial kit (Dojindo Laboratories, Tokyo, Japan) was used for the determination of $\mathrm{NO}_{\mathrm{x}}$. After indicated times of incubation, $80 \mu \mathrm{l}$ of cell-free culture supernate were collected, and the amount of $\mathrm{NO}_{\mathrm{x}}$ was assayed according to the manufacturer's instructions. Absorbances were read with a Victor ${ }^{\mathrm{TM}}$ Multilabel Counter (Wallac Oy, Turku, Finland) at a wavelength of $540 \mathrm{~nm}$.

\section{Western blot analysis}

Henle-407 cells, with or without infection with $S$. Enteritidis, were harvested after indicated times of incubation and washed with phosphate-buffered saline (PBS). Cell lysates were made as previously described [11]. Briefly, $75 \mu \mathrm{l}$ of lysis buffer containing $150 \mathrm{mM}$ $\mathrm{NaCl}, 10 \mathrm{~mm}$ Tris, pH 7.2, $1.5 \mathrm{mM} \mathrm{MgCl}_{2}$, Triton X$1001 \%$ and a cocktail of protease inhibitors (5 mM DLdithiothreitol, $10 \mu \mathrm{g} / \mathrm{ml}$ trypsin-chymotrypsin inhibitor $10 \mu \mathrm{g} / \mathrm{ml}, 1 \mathrm{mM}$ PMSF, pepstatin A $10 \mu \mathrm{g} / \mathrm{ml}$, leupeptin $10 \mu \mathrm{g} / \mathrm{ml}$, antipain $10 \mu \mathrm{g} / \mathrm{ml}, 1 \mathrm{mM} \mathrm{NaN}_{3}$, aprotinin $1 \%$ and $1 \mathrm{mM}$ EDTA) was added to the pellet of $2 \times 10^{6}$ viable cells and incubated for $2 \mathrm{~h}$ at $4^{\circ} \mathrm{C}$ with constant rocking. The cell lysates were then centrifuged for $30 \mathrm{~min}$ at $4^{\circ} \mathrm{C}(12000 \mathrm{~g})$ and the supernates were collected. The cell lysates were stored at $-20^{\circ} \mathrm{C}$ until used.

Lysates $(75 \mu \mathrm{l})$ were mixed with $25 \mu \mathrm{l}$ of five-fold Laemmli's sample buffer with reduction and incubated for $20 \mathrm{~min}$ at $37^{\circ} \mathrm{C}$. The samples were loaded on to a sodium dodecyl sulphate polyacrylamide $5-12.5 \%$ gel. Resolved proteins were transferred on to nitrocellulose membranes (Hybond-ECL, Amersham, UK). Antigen was detected with a monoclonal antibody (MAb) against mouse iNOS enzyme (Transduction Laboratories, Kentucky, USA) that is known to cross-react with human iNOS. Bound secondary antibody, horseradish peroxidase-conjugated rabbit anti-mouse IgG, was detected with the enhanced chemiluminescence (ECL) technique according to the manufacturer's instructions (Amersham). As a negative control antibody, a subclass matched (IgG2a) MAb KIT-2C75 against the chicken tyrosine kinase-type receptor for haemopoietic stem cell factor was used [12] (from Dr Olli Vainio, Department of Medical Microbiology, University of Turku, Finland). 


\section{$R T-P C R$}

Henle-407 cells, with or without infection with $S$. Enteritidis, were harvested after indicated periods of incubation and washed with PBS. Lysis buffer $(350 \mu \mathrm{l})$ was added to the pellet of $1 \times 10^{7}$ viable cells and the lysate was stored at $-70^{\circ} \mathrm{C}$ until used. Details of RNA extraction and reverse transcription (RT)-PCR were described previously [13]. Briefly, total RNA was extracted from the pelleted cells with the RNeasy kit (QIAGEN, Hilden, Germany) according to the manufacturer's instructions. Extracted RNA was first treated with DNase I (Gibco BRL, MD, USA) and then used for cDNA synthesis in the SuperScript ${ }^{\mathrm{TM}}$ Pre-amplification System (Gibco). The primers specific for iNOS (5'-ATG CCA GAT GGC AGC ATC AGA-3' and 5'ACT TCC TCC AGG ATG TTG TA-3') [14] and $\beta$ actin (5'-GAA ATC GTG CGT GAC ATT AAG GAG$3^{\prime}$ and 5'-ATA CTC CTG CTT GCT GAT CCA CAT$\left.3^{\prime}\right)$ [13] were used. PCR reactions were run with a thermal reactor (TouchDown, Hybaid, Middlesex, UK). RT-PCR assays were first optimised and the number of cycles used was adjusted to ensure that PCR products were analysed before they reached saturation. The differences in RNA isolation and cDNA synthesis were normalised to a housekeeping gene, $\beta$-actin. The PCR reaction mixture of $50 \mu \mathrm{l}$ contained $10 \mathrm{mM}$ Tris- $\mathrm{HCl}$ (pH 8.8), $1.5 \mathrm{mM} \mathrm{MgCl}_{2}, 50 \mathrm{mM} \mathrm{KCl}$, Triton X-100 $0.1 \%, 200 \mu \mathrm{M}$ of each dNTP, and 1 (or 0.5 ) unit of DNA polymerase (DynaZyme ${ }^{\mathrm{TM}}$, Finnzymes, Espoo, Finland). The primer concentration was 10 pmol for $\beta$ actin and $20 \mathrm{pmol}$ for iNOS. Initial denaturation at $94^{\circ} \mathrm{C}$ for $5 \mathrm{~min}$ and final extension at $72^{\circ} \mathrm{C}$ for $5 \mathrm{~min}$ were used for both primers. For $\beta$-actin, 30 cycles of $94^{\circ} \mathrm{C}$ for $1 \mathrm{~min}, 60^{\circ} \mathrm{C}$ for $30 \mathrm{~s}$, and $72^{\circ} \mathrm{C}$ for $1 \mathrm{~min}$ were used, and for iNOS 40 cycles of $94^{\circ} \mathrm{C}$ for $1 \mathrm{~min}, 62^{\circ} \mathrm{C}$ for $1 \mathrm{~min}$ and $72^{\circ} \mathrm{C}$ for $2 \mathrm{~min}$ were used. The resulting PCR products $(16 \mu \mathrm{l})$ were analysed by electrophoresis in agarose $1.5 \%$ gels and stained with ethidium bromide.

\section{Results}

\section{Production of NO by infected Henle cells}

Stable metabolites of NO that accumulated in the cell culture supernates were measured to determine the NO production by the cells. $\mathrm{NO}$ is rapidly converted to $\mathrm{NO}_{2}$ and $\mathrm{NO}_{3}$ in oxygenated solutions. As the ratio of $\mathrm{NO}_{2} / \mathrm{NO}_{3}$ can vary in the course of infection it may not be adequate to measure only nitrite in the supernates. Therefore, nitrate was first converted to nitrite and the total amount of the nitrite, reflecting the NO production of the cells, was measured.

$S$. Enteritidis induced production of $\mathrm{NO}$ in parent Henle cells but not in Henle-NO ${ }^{\text {def }}$ cells (Fig. 1). Increased $\mathrm{NO}_{\mathrm{x}}$ levels could already be detected in parent Henle cells 1 day after infection and, in 1 week, the cumulative production of nitrite exceeded $100 \mu \mathrm{M}$.

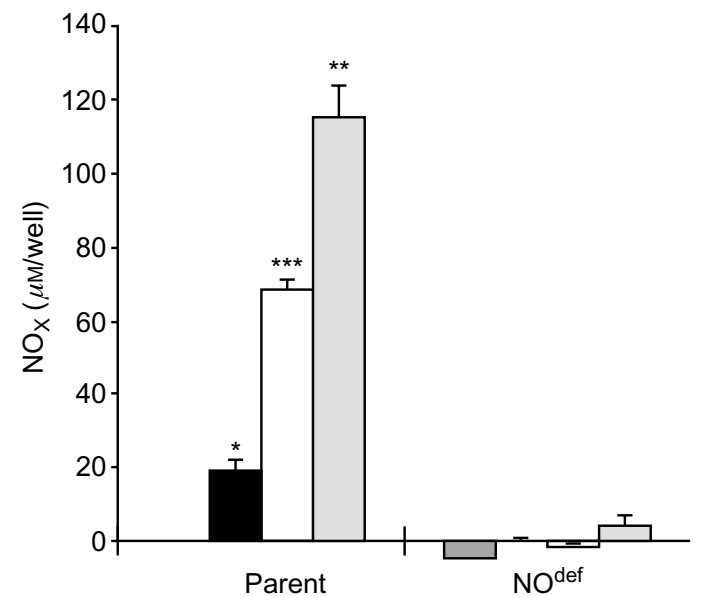

Fig. 1. Production of NO by salmonella-infected parent (parent) and NO-deficient ( $\left.\mathrm{NO}^{\text {def }}\right)$ Henle-407 cells. Cells were infected with $S$. Enteritidis and, after $1 \mathrm{~h}(\square), 1(\square), 3(\square)$ and $6(\square)$ days, the cumulative production of NO by the cells was measured as $\mathrm{NO}_{\mathrm{x}}$. Values are the means and SD of a representative experiment out of three with similar results; ${ }^{*} \mathrm{p}<0.02$, ${ }^{* *} \mathrm{p}<0.05,{ }^{* * *} \mathrm{p}=0.001$ compared with Henle-NO ${ }^{\text {def }}$ cells.

\section{Elimination of $S$. Enteritidis in Henle cells}

Confluent monolayers of parent Henle and Henle-NO ${ }^{\text {def }}$ cells were infected with $S$. Enteritidis, and the number of viable intracellular bacteria was determined by $\mathrm{cfu}$ counts after the indicated periods.

Equal amounts of bacteria were found in parent Henle and Henle-NO ${ }^{\text {def }}$ cells (Fig. 2). During the first day after infection, the number of viable bacteria increased in both cell lines. Elimination of $S$. Enteritidis in parent Henle and Henle-NO ${ }^{\text {def }}$ cells did not differ significantly $(p>0.05)$ from each other based on four independent experiments. The viability of the cells was found to be equal in parent and Henle-NO ${ }^{\text {def }}$ cell lines, determined at each time point by trypan blue exclusion.

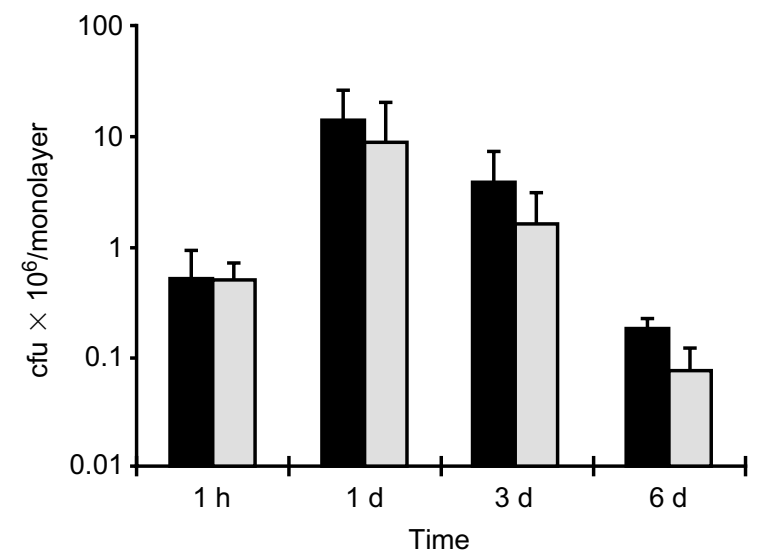

Fig. 2. The number of viable intracellular bacteria in parent (ם) and NO-deficient ( $\square$ ) Henle-407 cells after salmonellainfection. Cells were infected with $S$. Enteritidis, and after indicated periods, the cells were lysed and viable bacteria were counted as cfu. Values are the means and SD of two experiments. 
The presence of $A G$ in the cell culture medium decreased the amount of $\mathrm{NO}_{\mathrm{x}}$ in cell culture supernates of infected parent Henle cells to the levels measured in uninfected cells (Fig. 3a), but AG did not have any effect on the elimination of the bacteria (Fig. 3b). In conclusion, no association was observed between production of NO and the elimination of $S$. Enteritidis in Henle cells.

\section{Intracellular expression of iNOS protein}

Western blot analysis was used to evaluate whether the amount of iNOS protein in cell lysates would correlate with the amount of nitrite measured in cell culture media. This was done to confirm that the nitrite measured in the cell culture supernate was a derivative of NO which, in turn, was synthesised by cellular iNOS and had not originated, for instance, from bacterial nitrous metabolism.

In Western blot analysis, the $130-\mathrm{kDa}$ protein indicating iNOS was detected in parent Henle cells 1 day

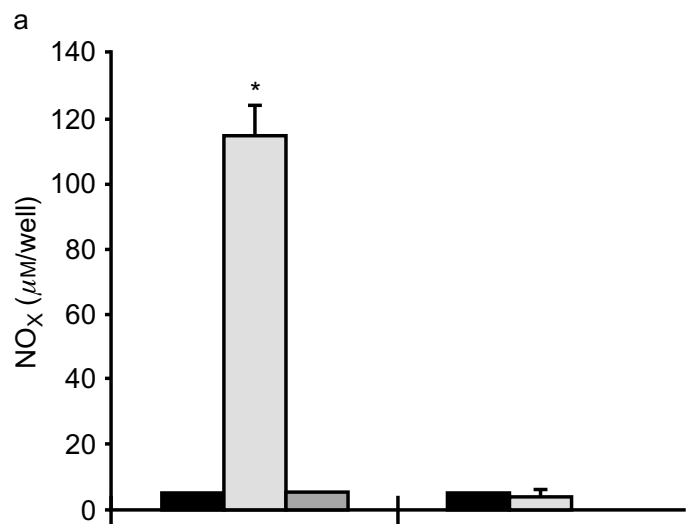

b

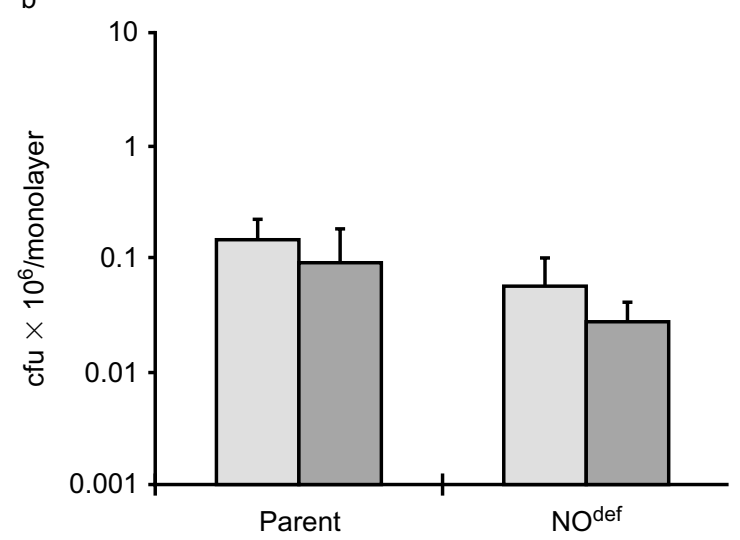

Fig. 3. Effect of the iNOS inhibitor aminoguanidine on production of NO (a), and elimination of intracellular $S$. Enteritidis (b) by Henle-407 cells. (a) Six days after infection the cumulative production of $\mathrm{NO}$ was measured as $\mathrm{NO}_{\mathrm{x}}$ in noninfected ( $\square$ ), salmonella-infected $(\square)$ and salmonella-infected and aminoguanidine-treated ( $\square$ ) cells. (B) Six days after infection the cells were lysed and the number of viable bacteria were counted as cfu. Values are the means and SD of a representative experiment out of three with similar results; ${ }^{*} \mathrm{p}<0.05$ compared with Henle-NO ${ }^{\text {def }}$ cells. after infection with $S$. Enteritidis (Fig. 4). The intensity of the band was greatest 1 day after infection and weakened thereafter, but was still detectable 6 days after infection. Salmonella infection did not induce the synthesis of iNOS protein in Henle-NOdef cells. The $130-\mathrm{kDa}$ band was not detected in non-infected Henle cells or in either of the salmonella-infected Henle cells $1 \mathrm{~h}$ after infection. Thus, the amounts of iNOS protein detected in the cell lysates of salmonella-infected Henle cells corresponded with the $\mathrm{NO}_{\mathrm{x}}$ levels measured in the respective cell culture supernates. A strongly positive band of $130 \mathrm{kDa}$ was detected in cell lysates of IFN- $\gamma$ - and LPS-stimulated murine macrophage J774.A1 cells which were used as a positive control for iNOS. The specificity of the signal was confirmed with unstimulated J774.A1 cells. A subclass matched antibody was used as a negative control in all experiments.

\section{Detection of iNOS mRNA}

The iNOS mRNA in the cell lysates was determined by RT-PCR. In the lysates of infected parent Henle cells, iNOS mRNA was detected only at 1 day after infection and not at the other time points (Fig. 5). In the Henle$\mathrm{NO}^{\text {def }}$ cells, no iNOS mRNA was detected even in the samples of salmonella-infected cells. Thus, these results corresponded with the iNOS protein levels detected by Western blot analysis.

\section{Discussion}

Intestinal epithelium serves as an important barrier against pathogenic microbes in the gut lumen. In addition to the purely physical character of this barrier it also has many biochemical and immunological functions that are essential for host defence against mucosal infections. $\mathrm{NO}$ is one of the mediators involved in these defence mechanisms. However, the large amounts of NO produced by iNOS during

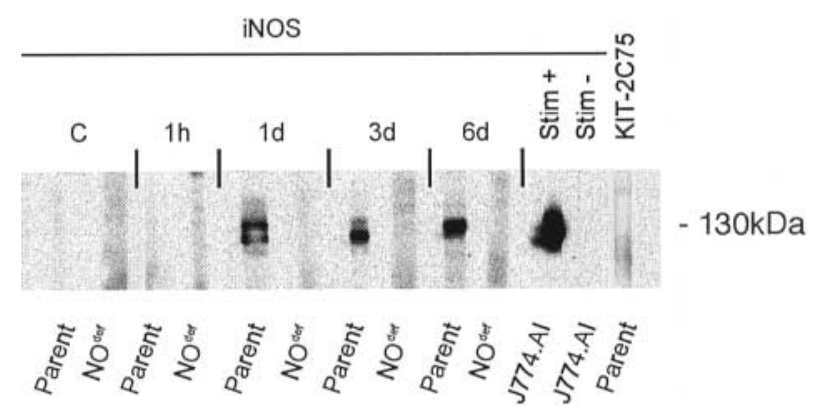

Fig. 4. Western blot analysis of iNOS protein synthesis in parent and NO-deficient Henle-407 cells. iNOS protein was analysed in cell lysates of non-infected (C) and $S$. Enteritidisinfected cells after indicated periods. J774.A1 murine macrophages with or without stimulation with IFN- $\gamma$ and LPS were used as positive and negative controls. A subclass matched MAb KIT-2C75 was used as a control antibody (salmonellainfected parent Henle cells, time point of 1 day). 


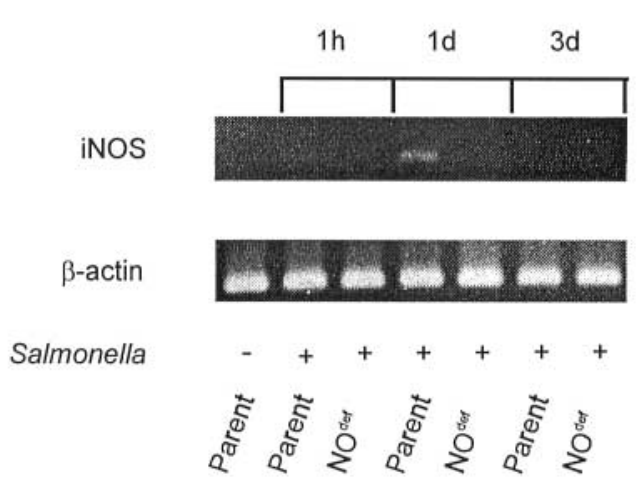

Fig. 5. Expression of iNOS mRNA in non-infected and salmonella-infected parent and NO-deficient Henle-407 cells. The cells were infected with $S$. Enteritidis, and the expression of iNOS mRNA was studied by RT-PCR.

infection do not necessarily only benefit the host, but can also have harmful effects, such as tissue injury and detrimental inflammation $[1,15]$. The capacity of human intestinal epithelial cells to produce NO has been studied recently with samples from patients with inflammatory bowel diseases (IBD) or by investigation of cultured enterocytes. Evidence exists for the role of NO, either direct or indirect, in the pathogenesis of IBD $[3,4,16,17]$. The source of NO in the inflamed human colon has been shown to be the intestinal epithelial cells rather than the adjacent inflammatory cells of the lamina propria $[18,19]$. How NO is linked to bowel inflammation is an interesting and still unresolved question, as it is not clear whether the main effect of NO is in the induction of inflammation in the gut or in resolving the intestinal inflammation [20].

Some pro-inflammatory cytokines, e.g., interleukin (IL) $-1 \beta$ and IFN- $\gamma$, stimulate the human intestinal epithelial cell line DLD-1 to produce NO [21]. Both of these cytokines are needed to induce iNOS synthesis in these cells and the regulation of iNOS gene expression probably includes post-transcriptional elements [22]. Intestinal epithelial cell lines seem to differ from each other in their capacity to produce $\mathrm{NO}$ as well as in the stimulants needed to induce NO production [8, 23, 24]. Some contradictory results have been presented about the capacity of enteroinvasive bacteria to induce iNOS. According to Salzman et al. DLD-1 and Caco-2BBe cells required another stimulus in addition to infection with $S$. Dublin to be able to produce NO [8], whereas Witthöft et al. showed that invasive bacteria could induce iNOS in Caco-2 and HT-29 cells independently of other stimuli [9]. The results of the present study suggest that $S$. Enteritidis is a sufficient stimulus for Henle-407 cells to induce iNOS mRNA and protein synthesis and release of NO.

In the present study, large quantities of nitrite were detected in cell culture supernates of $S$. Enteritidis-
NO IN SALMONELLA-INFECTED EPITHELIAL CELLS

infected parent Henle-407 cells, but not in Henle-NO ${ }^{\text {def }}$ cells. Aminoguanidine, an iNOS selective inhibitor, clearly abolished the stimulatory effect of $S$. Enteritidis in parent Henle cells, supporting the assumption that nitrite in the cell-culture medium of infected Henle cells was an end product of NO synthesis by cellular iNOS. As a further confirmation, results obtained by Western blot analysis and RT-PCR concerning iNOS protein and mRNA levels were in line with the amounts of nitrite measured in cell culture media. The kinetics of iNOS mRNA and iNOS protein in parent Henle cells supported each other; the signals were at their strongest 1 day after infection, after which iNOS mRNA was undetectable and the amount of iNOS protein diminished gradually.

The antimicrobial properties of NO have been studied widely $[25,26]$ and most of these studies indicate that phagocytic cells are the main source of antimicrobial NO. Whether NO is used in mucosal epithelium to eliminate pathogenic microbes is not entirely clear. There are some data suggesting a role for NO produced by epithelial-T cell interaction in the inhibition of intracellular growth of $C$. trachomatis $[7,27,28]$. However, studies performed with iNOS knockout mice indicated that NO is not essential for the clearance of C. trachomatis from the epithelial cells lining the female genital tract $[29,30]$. Nevertheless, it may contribute to the control of the general dissemination of $C$. trachomatis. In human intestinal epithelial cell lines, $S$. Dublin augmented NO production in IFN- $\gamma$ primed cells [8], and stimulation of NO production could also be seen after infection with Escherichia coli and Shigella flexneri [9], but neither of these studies analysed the effect of released NO in the elimination of the bacteria.

The present work showed that production of NO by $S$. Enteritidis-infected cells was not associated with elimination of bacteria, indicating that NO would not directly be of essential importance in killing of intracellular $S$. Enteritidis in intestinal epithelial cells. This was demonstrated by experiments with a NOdeficient transfected Henle cell line and inhibition of NO production in parent Henle cells by AG. Although they do not have the massive antimicrobial machinery, like professional phagocytes, intestinal epithelial cells do have some innate defence mechanisms against microbes, e.g., lysozyme [31], defensins [32], phospholipase A2 [33] and histone $\mathrm{H} 1$ proteins [34]. It is likely that, during infection, epithelial cells have a more important role in attracting neutrophils and other phagocytic cells to help in the elimination of pathogens than eliminating microbes themselves $[35,36]$. It has been reported that two derivatives of NO, S-nitrosoglutathione (GSNO) and peroxynitrite, do mediate cytostasis and killing of $S$. Typhimurium, although pure NO - does not have antibacterial activity [37]. Thus, it is possible that NO produced by intestinal epithelial cells in vivo could interact with superoxide secreted by 
phagocytic cells in the lamina propria to form peroxynitrite, or react with glutathione to form GSNO. Furthermore, NO has been shown to trigger exocytosis of human colonic mucus-secreting epithelial cells [38] and also play a part in the secretion of intestinal fluid [39-41], both of which may potentiate host defence against pathogens in the gut lumen. Accordingly, it is not excluded that NO produced by intestinal epithelial cells in vivo could, in concert with other cells, have a role in the elimination of pathogenic microbes in the mucosal epithelium. In particular, this may be the case in the gut where the oxygen tension is relatively low and the half-life of NO is longer than in normoxic conditions which are present in the cell culture.

The infection protocol used in the present study has been widely used when the interaction between cells and microbes has been investigated. However, although gentamicin is usually considered to be a membraneimpermeant antibiotic, a recent study has suggested that the concentration of extracellular gentamicin may affect the bactericidal capacity of macrophages against Listeria monocytogenes [42]. That study indicates that macrophages are able to deliver pinocytosed extracellular fluid to phagosomes containing bacteria, that may then interfere with the results of the experiments. The physiological absorption function of intestinal epithelial cells makes it probable that gentamicin may also exist intracellularly in Henle cells after infection. However, whether it co-localises with the bacteria is unknown. Accordingly, when the mechanisms of elimination of salmonellae by Henle cells are considered, the possibility that gentamicin also plays a role in the elimination of intracellular bacteria should not be ignored. Moreover, cell death during the incubation of several days with subsequent exposure of bacteria to gentamicin surely plays a role, albeit a minor role, in reducing the number of live bacteria in the cell culture. These possible effects of gentamicin in killing the bacteria do not alter the fact that NO did not have a role in the elimination of the bacteria, as the dramatic difference observed in the production of NO did not influence the number of viable intracellular bacteria.

Taken together, the results of the present work provide evidence that intracellular elimination of $S$. Enteritidis by human intestinal epithelial cells is mediated by mechanisms other than NO. Inducible NO may still play a part either directly or indirectly in the host defence against enteropathogenic microbes in the gut in vivo, as the mucosal immune system consists of a complex network of different signalling pathways in which virtually all components affect each other.

We thank Tiina Lähde and Erkki Nieminen for excellent technical assistance, and Dr Marko Salmi for valuable advice. We also acknowledge Dr David Smith for revising the language. This work was supported by the European Commission Biomed 2 Programme BMH4-CT96-1056, the Finnish Academy, the Sigrid Jusélius Foundation, the Paulo Foundation and the Foundation of the University of Turku.

\section{References}

1. Nathan C. Inducible nitric oxide synthase: what difference does it make? J Clin Invest 1997; 100: 2417-2423.

2. Clancy RM, Amin AR, Abramson SB. The role of nitric oxide in inflammation and immunity. Arthritis Rheum 1998; 41: 1141-1151.

3. Middleton SJ, Shorthouse M, Hunter JO. Increased nitric oxide synthesis in ulcerative colitis. Lancet 1993; 341: 465-466.

4. Boughton-Smith NK, Evans SM, Hawkey CJ et al. Nitric oxide synthase activity in ulcerative colitis and Crohn's disease. Lancet 1993; 342: 338-340.

5. Aiko S, Grisham MB. Spontaneous intestinal inflammation and nitric oxide metabolism in HLA-B27 transgenic rats. Gastroenterology 1995; 109: 142-150.

6. Rachmilewitz D, Karmeli F, Okon E. Sulfhydryl blocker-induced rat colonic inflammation is ameliorated by inhibition of nitric oxide synthase. Gastroenterology 1995; 109: 98-106.

7. Igietseme JU, Uriri IM, Chow M, Abe E, Rank RG. Inhibition of intracellular multiplication of human strains of Chlamydia trachomatis by nitric oxide. Biochem Biophys Res Commun 1997; 232: 595-601.

8. Salzman AL, Eaves-Pyles T, Linn SC, Denenberg AG, Szabó C. Bacterial induction of inducible nitric oxide synthase in cultured human intestinal epithelial cells. Gastroenterology 1998; 114: 93-102.

9. Witthöft T, Eckmann L, Kim JM, Kagnoff MF. Enteroinvasive bacteria directly activate expression of iNOS and NO production in human colon epithelial cells. Am $J$ Physiol 1998; 275: G564-G571.

10. Saarinen M, Pelliniemi LJ, Granfors K. Survival and degradation of Salmonella enterica serotype Enteritidis in intestinal epithelial cells in vitro. J Med Microbiol 1996; 45: 463-471.

11. Salmi M, Jalkanen S. Different forms of human vascular adhesion protein-1 (VAP-1) in blood vessels in vivo and in cultured endothelial cells: implications for lymphocyte-endothelial cell adhesion models. Eur J Immunol 1995; 25: 2803-2812.

12. Vainio O, Dunon D, Aïssi F, Dangy J-P, McNagny KM, Imhof BA. HEMCAM, an adhesion molecule expressed by c-kit $^{+}$hemopoietic progenitors. J Cell Biol 1996; 135: $1655-1668$.

13. He Q, Minh NNT, Edelman K, Viljanen MK, Arvilommi H, Mertsola J. Cytokine mRNA expression and proliferative responses induced by pertussis toxin, filamentous hemagglutinin, and pertactin of Bordetella pertussis in the peripheral blood mononuclear cells of infected and immunized schoolchildren and adults. Infect Immun 1998; 66: 3796-3801.

14. Vouldoukis I, Riveros-Moreno V, Dugas B et al. The killing of Leishmania major by human macrophages is mediated by nitric oxide induced after ligation of the FceRII/CD23 surface antigen. Proc Natl Acad Sci USA 1995; 92: 7804-7808.

15. Fang FC. NO contest: nitric oxide plays complex roles in infection. ASM News 1997; 63: 668-673.

16. Lundberg JO, Hellström PM, Lundberg JM, Alving K. Greatly increased luminal nitric oxide in ulcerative colitis. Lancet 1994; 344: $1673-1674$.

17. Kimura H, Hokari R, Miura S et al. Increased expression of an inducible isoform of nitric oxide synthase and the formation of peroxynitrite in colonic mucosa of patients with active ulcerative colitis. Gut 1998; 42: 180-187.

18. Singer II, Kawka DW, Scott S et al. Expression of inducible nitric oxide synthase and nitrotyrosine in colonic epithelium in inflammatory bowel disease. Gastroenterology 1996; 111: $871-885$.

19. Kolios G, Rooney N, Murphy CT, Robertson DAF, Westwick J. Expression of inducible nitric oxide synthase activity in human colon epithelial cells: modulation by $\mathrm{T}$ lymphocyte derived cytokines. Gut 1998; 43: 56-63.

20. McCafferty D-M, Mudgett JS, Swain MG, Kubes P. Inducible nitric oxide synthase plays a critical role in resolving intestinal inflammation. Gastroenterology 1997; 112: 1022-1027.

21. Salzman AL, Denenberg AG, Ueta I, O'Connor M, Linn SC, Szabó C. Induction and activity of nitric oxide synthase in cultured human intestinal epithelial monolayers. Am J Physiol 1996; 270: G565-G573.

22. Linn SC, Morelli PJ, Edry I, Cottongim SE, Szabó C, Salzman AL. Transcriptional regulation of human inducible nitric oxide synthase gene in an intestinal epithelial cell line. Am J Physiol 1997; 272: G1499-G1508. 
23. Jenkins DC, Charles IG, Baylis SA, Lelchuk R, Radomski MW, Moncada S. Human colon cancer cell lines show a diverse pattern of nitric oxide synthase gene expression and nitric oxide generation. $\mathrm{Br} J$ Cancer 1994; 70: 847-849.

24. Kolios G, Brown Z, Robson RL, Robertson DAF, Westwick J. Inducible nitric oxide synthase activity and expression in a human colonic epithelial cell line, HT-29. Br J Pharmacol 1995; 116: $2866-2872$.

25. De Groote MA, Fang FC. NO inhibitions: antimicrobial properties of nitric oxide. Clin Infect Dis 1995; 21 Suppl 2: S162-S165.

26. Fang FC. Mechanisms of nitric oxide-related antimicrobial activity. J Clin Invest 1997; 99: 2818-2825.

27. Igietseme JU. The molecular mechanism of T-cell control of Chlamydia in mice: role of nitric oxide. Immunology 1996; 87: $1-8$.

28. Igietseme JU, Uriri IM, Hawkins R, Rank RG. Integrin-mediated epithelial-T cell interaction enhances nitric oxide production and increased intracellular inhibition of Chlamydia. J Leukoc Biol 1996; 59: 656-662.

29. Perry LL, Feilzer K, Caldwell HD. Neither interleukin-6 nor inducible nitric oxide synthase is required for clearance of Chlamydia trachomatis from the murine genital tract epithelium. Infect Immun 1998; 66: 1265-1269.

30. Igietseme JU, Perry LL, Ananaba GA et al. Chlamydial infection in inducible nitric oxide synthase knockout mice. Infect Immun 1998; 66: 1282-1286.

31. Erlandsen SL, Parsons JA, Taylor TD. Ultrastructural immunocytochemical localization of lysozyme in the Paneth cells of man. J Histochem Cytochem 1974; 22: 401-413.

32. Selsted ME, Miller SI, Henschen AH, Ouellette AJ. Enteric defensins: antibiotic peptide components of intestinal host defense. J Cell Biol 1992; 118: 929-936.

33. Harwig SS, Tan L, Qu X-D, Cho Y, Eisenhauer PB, Lehrer RI.
Bactericidal properties of murine intestinal phospholipase $\mathrm{A}_{2}$. $J$ Clin Invest 1995; 95: 603-610.

34. Rose FRAJ, Bailey K, Keyte JW, Chan WC, Greenwood D, Mahida YR. Potential role of epithelial cell-derived histone H1 proteins in innate antimicrobial defence in the human gastrointestinal tract. Infect Immun 1998; 66: 3255-3263.

35. Kagnoff MF, Eckmann L. Epithelial cells as sensors for microbial infection. J Clin Invest 1997; 100: 6-10.

36. Sansonetti PJ, Arondel J, Huerre M, Harada A, Matsushima K. Interleukin-8 controls bacterial transepithelial translocation at the cost of epithelial destruction in experimental shigellosis. Infect Immun 1999; 67: 1471-1480.

37. De Groote MA, Granger D, Xu Y, Campbell G, Prince R, Fang FC. Genetic and redox determinants of nitric oxide cytotoxicity in a Salmonella typhimurium model. Proc Natl Acad Sci USA 1995; 92: 6399-6403.

38. Branka JE, Vallette G, Jarry A, Laboisse CL. Stimulation of mucin exocytosis from human epithelial cells by nitric oxide: evidence for a cGMP-dependent and a cGMP-independent pathway. Biochem J 1997; 323: 521-524.

39. Mourad FH, O'Donnell LJD, Andre EA et al. L-Arginine, nitric oxide, and intestinal secretion: studies in rat jejunum in vivo. Gut 1996; 39: 539-544.

40. Mourad FH, Turvill JL, Farthing MJG. Role of nitric oxide in intestinal water and electrolyte transport. Gut 1999; 44: $143-147$.

41. Closs EI, Enseleit F, Koesling D, Pfeilschifter JM, Schwarz PM, Förstermann U. Coexpression of inducible NO synthase and soluble guanylyl cyclase in colonic enterocytes: a pathophysiologic signalling pathway for the initiation of diarrhea by gramnegative bacteria? FASEB 1998; 12: 1643-1649.

42. Drevets DA, Canono BP, Leenen PJM, Campbell PA. Gentamicin kills intracellular Listeria monocytogenes. Infect Immun 1994; 62: 2222-2228. 